\title{
Mentődolgozók és mentőtiszthallgatók halállal és haldoklással kapcsolatos attitüdjének összehasonlító vizsgálata
}

\author{
Pék Emese $^{1}$ - Székely-Benke Zoltán ${ }^{1}$ - Betlehem József dr. ${ }^{1}$ - Fullér Noémi² \\ Pécsi Tudományegyetem, Egészségtudományi Kar, 'Sürgősségi Ellátási és Egészségpedagógiai Intézet, \\ 22Ápolástudományi, Alapozó Egészségtudományi és Védőnői Intézet, Pécs
}

\begin{abstract}
Bevezetés: A sürgősségi betegellátás dolgozói nap mint nap szemtanúi a haldoklás és a halál élményének. Célkitüzés: A vizsgálat célja a jelenlegi és jövőbeli mentődolgozók körében a halálfélelem és az azt befolyásoló tényezők felmérése és összehasonlítása. Módszer: A kvantitatív, keresztmetszeti, összehasonlító vizsgálat 106 fő részvételével készült (mentődolgozó 45 fő, mentőtiszthallgató 61 fő). Az adatgyüjtés önkéntes alapon, anonim módon, kérdőíves módszerrel történt, a Neimeyer és Moore-féle Multidimenzionális Halálfélelem Skála és saját szerkesztésű kérdések segítségével. Az adatokat leíró és matematikai statisztikai próbák (T-próba, ANOVA-elemzés és korrelációanalízis) segítségével elemezték. Eredmények: A tanulók félelme nagyobb volt a „Jelentôs társak féltése” faktorban $(\mathrm{p}=0,001)$. Erőteljesebb félelmet mutattak azok a nói hallgatók, akik városban éltek, magasabb iskolai végzettségük volt $(\mathrm{p}=0,036)$, az egyedülállók ( $\mathrm{p}=0,046)$, akik még nem láttak haldoklót $(\mathrm{p}=0,017)$ és akik még nem voltak szemtanúi halál bekövetkeztének. A mentődolgozók közül erőteljesebb félelem jellemezte a faluban lakókat, a partnerkapcsolatban élőket $(\mathrm{p}=0,027)$, az alacsonyabb iskolai végzettséggel rendelkezőket $(\mathrm{p}=0,041)$ és akik régebb óta dolgoztak. Következtetések: A jelenlegi és a leendő mentődolgozók halálfélelmének mértékében nincs számottevő különbség. Nagyon fontos a gyakorlatorientált oktatás, továbbá a hallgatók képzési programjába be kell építeni a halállal és a haldoklással kapcsolatos képzést is. Orv. Hetil., 2015, 156(40), 1618-1624.
\end{abstract}

Kulcsszavak: halálfélelem, MFODS, mentődolgozók, mentőtiszthallgatók

\section{Comparative analysis of attitudes of ambulance personnel and paramedic students regarding death and dying}

Introduction: The emergency care staff witness the experience of dying and death on a daily basis. Aim: The aim of the study was to evaluate and compare the current and future ambulance personnel's fear of death and its influencing factors. Method: Quantitative, cross-sectional comparative study was conducted including 106 participants (active rescue ambulance personnel, $\mathrm{n}=45$ persons; paramedic students, $\mathrm{n}=61$ ). A voluntary, anonymous questionnaire survey method (the Neimeyer-Moore Multidimensional Fear of Death Scale) was used for data collection. The data were analyzed using descriptive and mathematical statistical tests (T-test, analysis of variance). Results: The students had a greater fear in the "Fear for Significant Others" factor $(\mathrm{p}=0.001)$. Students showed stronger fear who lived in cities, had higher educational qualifications, who where women $(\mathrm{p}=0.036)$, singles $(\mathrm{p}=0.046)$, those who have not seen a dying person $(\mathrm{p}=0.017)$ and those who were never witnessed death. Greater fear characterized the ambulance personnel who were village residents, those living in a partnership $(p=0.027)$, those with lower educational level $(\mathrm{p}=0.041)$ and those who had been working for a longer time. Conclusions: There is no significant difference between the levels of fear of death of the present and future ambulance personnel. However, the practice-oriented education is very important and, training associated with death and dying should be integrated in the educational schedules of the paramedic students.

Keywords: fear of death, MFODS, ambulance personnel, paramedic students

Pék, E., Székely-Benke, Z., Betlehem, J., Fullér, N. [Comparative analysis of attitudes of ambulance personnel and paramedic students regarding death and dying]. Orv. Hetil., 2015, 156(40), 1618-1624.

(Beérkezett: 2015. július 16.; elfogadva: 2015. augusztus 13.) 


\section{Rövidítések}

HADS = Hungarian Death Attitude Survey; MFODS $=($ Multidimensional Fear of Death Scale) Neimeyer és Moore-féle Multidimenzionális Halálfélelem Skála; OMSZ = Országos Mentőszolgálat; PTE = Pécsi Tudományegyetem

A halál az emberi kultúrák egyik legnagyobb misztikuma. Teljesen soha meg nem ismerhetô, mert át nem élhető. A halál jelentése kultúránként alapvetően más. A halálhoz való viszonyulás az adott kultúra és társadalmi rendszer hatására folyamatosan változik, de az ember, bár fél a haláltól, mégis kíváncsi. A saját halálunktól való félelmünk egy olyan negatív érzelmi reakció, amelyet egy olyan állapot felidézése provokál, amelyben az én nem létezik [1]. A mások halálától való félelem pedig pusztán a saját, szerettünk elvesztése miatti önsajnálatunk kivetítése [2]. A halálfélelem kérdésével való foglalkozást a jóléti társadalmak demográfiai és gazdasági változásai is indokolják.

$\mathrm{Az}$ átlagéletkor tartós emelkedése, valamint a születési arányszám csökkenése a lakosság létszámának csökkenését eredményezte a jóléti társadalmakban, ami számos egészségügyi, nyugdíj-biztosítási és szociális problémát von maga után. Magyarország lakossága 2013-as adatok alapján 9908000 fó volt, az élve születések száma ebben az évben 88700 , míg a halálozások száma 126801 fó volt, így a természetes szaporulat -38100 fó volt. A születéskor várható élettartam soha nem látott magasságot ért el 2012-ben, ami férfiak esetében 71,45 évet, nők esetében 78,38 évet jelentett. A férfiak 6,3 évvel, a nők 4,7 évvel számíthattak hosszabb életre, mint 1990ben. A korcsoportokat tekintve 1990-ben a népesség 19\%-a volt 60 év feletti (1 959846 fó), ez az arány 2011-re jelentősen megemelkedett (23\%, 2331111 fö). Az elöregedő társadalom problémáját súlyosbítja továbbá az is, hogy a 0-14 éves korosztály aránya csökkenő tendenciát mutat $[3,4]$.

Az idősek számának rohamos növekedése nem elhanyagolható terhet ró az egészségügyi ellátórendszerre, ennek is egy speciális ágára, a sürgősségi betegellátásra. Ezek a páciensek más lehetőségük hiányában nagyon gyakran riasztják az Országos Mentőszolgálat (OMSZ) dolgozóit.

A témához szorosan kapcsolódik a halál és a haldoklás problémaköre, amely a népesség e csoportját természetes módon és letális betegségek képében is sújtja. Megváltozott a haldoklás helyszíne, aminek következtében a haldoklók gondozása a család helyett az egészségügy feladatává vált. Bár az emberek $60 \%$-a továbbra is otthonában, családtagjai körében szeretné tölteni életének utolsó időszakát, a haldoklók kétharmada mégis kórházban hal meg $[5,6]$. Éppen ezért elengedhetetlen, hogy a prehospitális ellátásban jelenleg tevékenykedők és a jövőben dolgozni kívánók halállal, haldoklással kapcsolatos hozzáállásával foglalkozzunk. A dolgozók kénytelenek felkészülni erre az akár mindennapos élményre, szükség ese- tén különböző megküzdési technikákat is elsajátítani a tapasztalások feldolgozására a zavartalan munkavégzés érdekében [7].

\section{A halálfélelem alakulása hazánkban}

A halálfélelem mérésére kiválóan alkalmas kutatási eszköz, a Neimeyer és Moore-féle Multidimenzionális Halálfélelem Skála (MFODS) [8] hazai validálására 2006-ban került sor, Zana Ágnes és munkatársai által, egy 178 fős mintán. A kapott adatok érvényességét a Lester-féle Halál Iránti Attitúd Skálával, a Rövidített Beck Depresszió Kérdőívvel és a STAI-T skálával ellenőrizték. Jelen vizsgálat szerint a három legjelentősebb félelmet keltô faktor a magyar átlagnépesség körében a "Jelentôs társak féltése”, a „Félelem a meghalás folyamatától” és a „Félelem a halottól” faktorok voltak [9].

A hazai átlagnépesség körében 2009-ben szintén készült egy felmérés, ami a halálfélelmet, halál iránti attitüdöt és a leginkább félelmet keltő faktorokat vizsgálta. A kérdőíves felmérés 617 fő részvételével történt, amelyből a késóbbiekben megszületett a HADS-adatbázis (Hungarian Death Attitude Survey).

A halálfélelem és a nemek viszonyát vizsgálva a korábbi külföldi és hazai kutatások is legtöbbször a nők erősebb halálfélelmét igazolták, magasabb általános szorongásszintjükkel magyarázva azt $(\mathrm{p}<0,001)[10,11]$. A nőknél és a férfiaknál is egyaránt a leginkább félelmet keltő faktorok rangsora a következő: 1. „Jelentős társak féltése", 2. „Félelem a meghalás folyamatától”, 3. A „Félelem a balottól”.

Az életkor tekintetében a halálhoz való viszonyulás három fó időszakra osztható. Serdülőkorban a bekövetkezett intellektuális fejlődés miatt a fiatal felnőtteknél már lehetővé válik a halál elkerülhetetlenségének megértése, ennek ellenére inkább igyekeznek nem foglalkozni a gondolattal. Az élet közepén az emberek rádöbbennek, hogy ettól kezdve „már nem felnőnek, hanem megöregszenek". Erre a szakaszra a halálfélelem erősödése a jellemző. Az öregkor felé közeledve a félelmet a halál elfogadásának különböző formái váltják fel. Jelen vizsgálatban a korosztályos összehasonlításban a fiatalok halálfélelme mutatkozott a legerősebbnek, a félelem mértéke negatívan korrelált az életkorral és fokozatosan csökkent a kor előrehaladtával. Szignifikáns különbség mutatkozott a korcsoportok között a „Jelentös társak féltése”, a „Félelem a meghalás folyamatától”, a „Félelem a halottól”, a „Félelem a balál tudatos átéléséto"l” és „A test féltése a halál után” faktorokban $(\mathrm{p}<0,001)$. A Lester-skála eredményei alapján szintén szignifikáns különbség volt a korcsoportok között, itt is a fiatalok halálfélelme bizonyult a legerősebbnek $(\mathrm{p}<0,001)$ [12].

A korábban már említett okokból kifolyólag az egészségügyben dolgozók jóval nagyobb stresszhatásnak vannak kitéve [13, 14, 15], fokozottabban érintettek a probléma szempontjából. Egy 2001-ben készült felmérés már konkrétan foglalkozott a témával, hogy felmérje 
a medikusok és ápolók halállal kapcsolatos attitüdjeit, valamint azzal a kérdéssel, hogy a leendő egészségügyi dolgozókat mennyire készítik fel képzésük során ezeknek a problémáknak a kezelésére. A haldoklók gondozása speciális szakmai ismereteket igényel az ápolóktól: kezelési, gondozási, etikai, pszichológiai, szociális és spirituális problémákkal kell szembesülniük. Az orvosok számára jelentős nehézséget jelent a betegek érzelmi labilitása, a düh kezelése, a kezelés visszautasítása, a rossz prognózisról való beszélgetés, valamint az elhunyt beteg hozzátartozóival való kommunikáció. A 4600 órás ápolóképzés során összesen 33 óra, míg a 7000 órás orvosi curriculum során 34 óra jut ezekre a témákra. Az egészségügyi dolgozók halálfélelme az átlagpopulációhoz képest szignifikánsan alacsonyabbnak bizonyult, csakúgy, mint a medikushallgatók eredményei az egyéb felsőoktatási intézményben tanulókéhoz képest. Utóbbi csoporthoz képest az ápolók és a medikusok halálfélelme jelentősen magasabbnak bizonyult a „Jelentös társak féltése", a „Félelem a meghalás folyamatától” faktorokban. Az eredmények alapján elmondható, hogy az ápolóknak csupán 22,4\%-a, míg a medikusoknak 3,8\%-a gondolta úgy, hogy tanulmányai során eleget foglalkozott a haldokló betegek ellátásával. A többség további ismereteit saját tapasztalatai révén szerezte. Elszomorító, hogy a válaszadók közel fele nem beszélget a haldoklókkal az ápolási kérdéseken kívüli témákról. Összességében ez a kutatás is bebizonyította, hogy az egészségügyi képzés és továbbképzés terén nagyon keveset foglalkoznak a halál kérdéskörével. Ugyanakkor a családban sem történik felkészítés ezen témák be-, illetve elfogadására [16]. Az Amerikai Egyesült Államokban az 1970-es évektől kezdődően [17], Magyarországon a '90-es évektől számolhatunk be hospice-szellemű speciális képzésekről. Sajnálatos módon a hazai, halállal és haldoklással kapcsolatos oktatás nem megfelelő hatékonyságát bizonyítja egy 2006-os utánkövetéses vizsgálat is. Annak ellenére, hogy az oktatás hatására a legtöbb faktorban csökkent a félelem mértéke, az ilyen jellegú tanfolyamok segítségével mégsem érhető el szignifikáns állapotváltozás.

Az egészségügyi dolgozók átlagpopulációhoz viszonyított halálfélelme kérdéses, a vizsgálatok eredményei nem egyöntetúek ezzel kapcsolatban. Míg egyes felmérések az átlagpopuláció tapasztalati hiányából fakadó jelentősebb mértékű félelméról számolnak be [18, 19], addig mások - pont az említett tapasztalásból kifolyólag - az egészségügyi dolgozók nagyobb halálfélelmét írják le $[12,20,21]$. Mind ez idáig a prehospitális ellátásban dolgozók félelmével nem foglalkoztak hazai kutatások.

A halálfélelem mértékének feltérképezése, az egyes dimenziók vizsgálata nagyban meghatározhatja a prevenciós lépések megfelelő időbeni meghozatalát és végső soron hozzájárulhat egy egészségesebb halálkép kialakulásához.

Mindezek ismeretében vizsgálatunk célja volt felmérni és összehasonlítani az Országos Mentőszolgálat kivonuló dolgozóinak és a Pécsi Tudományegyetem mentő- tiszthallgatóinak halálfélelmét, halállal és haldoklással kapcsolatos attitüdjét. További célként kitűzve a halálfélelem mértékét befolyásoló tényezők feltérképezését.

\section{Módszer}

Keresztmetszeti összehasonlító vizsgálatunkat, a szükséges írásos engedélyek beszerzését követően, a Pécsi Tudományegyetem Egészségtudományi Karának I-IV. éves mentőtiszthallgatói és az OMSZ marcali és fonyódi mentőállomásán kivonuló szolgálatot teljesítő, 18. életévüket betöltött mentődolgozói körében végeztük. A nem véletlenszerü kényelmi mintavételi eljárást követően a megkérdezettek önkéntes alapon, anonim módon vettek részt a kutatásban. A felmérésből kizárásra kerültek azok a mentőtiszthallgatók, akik tanulmányaik mellett az Országos Mentőszolgálatnál kivonuló szolgálatot teljesítettek.

Kérdőíves felmérésünk alapját a Neimeyer és Mooreféle Multidimenzionális Halálfélelem Skála képezte. Ez egy 42 tételből álló, 8 faktorra bontott skála, amely a halálfélelem faktoronként különböző területeit érinti, amely faktorok a következők:

I. Félelem a meghalás folyamatától (beleértve a fájdalmas, erőszakos halál): 1., 13., 22., 27., 31., 42. kérdés (6-30 pont).

II. Félelem a halottól (az emberi és állati tetemtól való félelmet egyaránt jelzi): 2., 14., 23., 26., 32., 39. kérdés (6-30 pont).

III. Félelem a megsemmisüléstől (beleértve a test oszlását vagy elégetését): 3., 15., 24., 33. kérdés (4-20 pont).

IV. Jelentős társak féltése (a számunkra fontos személyek halálától való félelem és a hozzátartozóink ránk irányuló aggodalma egyaránt beletartozik): 4., 16., 17., 25., 34., 37. kérdés (6-30 pont).

V. Félelem az ismeretlentől (félelem a létezés megszünésétől és a halál utáni élettől vagy annak hiányától): 5 ., 9., 18., 30., 36. kérdés (5-25 pont).

VI. Félelem a halál tudatos átélésétől (szorongás attól, hogy valakit tévesen holttá nyilvánítanak, bár még él): 6 ., 10., 19., 29., 38. kérdés (5-25 pont).

VII. A test féltése a halál után (félelem a test bomlásától és izolációjától): 7., 11., 20., 28., 35., 40. kérdés (6-30 pont).

VIII. Félelem a korai haláltól (miszerint nem érjük el a kitüzött céljainkat, nem valósíthatjuk meg vágyainkat): 8., 12., 21., 41. kérdés (4-20 pont).

A kitöltők 1-5-ig terjedő Likert-skálán válaszolhattak, mind a 42 állításra ( 1 - ha teljesen egyetért az állítással és 5 - ha egyáltalán nem ért egyet). A skála 5 kérdése természetéből eredően fordított értékelésú volt (3., 9., 14., 25. és 28. kérdés). A válaszadók összesen minimum 42 , maximum 210 pontot érhettek el. Az értékelés során minél kisebb pontszámot ért el a válaszadó, annál magasabb volt a halálfélelme az adott faktorban. Kutatási eszközünk kiegészült további, általunk szerkesztett saját 
kérdésekkel is (szociodemográfiai adatokra, munkavégzésre, tanulmányokra, halállal és haldoklással kapcsolatos előzetes tapasztalatokra vonatkozóan).

A kapott adatokat SPSS 17.0 statisztikai szoftver segítségével elemeztük, amely során leíró statisztikai eljárásokat (átlag- és gyakoriságszámítást), valamint matematikai statisztikai próbákat (T-próbát, varianciaanalízist és korrelációanalízist) végeztünk. A kapott eredményeket $\mathrm{p} \leq 0,05$ esetén tekintettük szignifikánsnak.

\section{Eredmények}

\section{Szociodemográfiai adatok}

A vizsgálat során összesen 106 fó adatait dolgoztuk fel $(\mathrm{N}=106)$ két csoportban: 45 fó OMSZ-dolgozó $(\mathrm{n}=$ 45 ) és 61 fö mentötiszthallgató vett részt a kutatásban (n =61). A nemek megoszlása szerint 45 fó nőt $(42,45 \%)$ és 61 fó férfit $(57,55 \%)$ kérdeztünk meg. Átlagéletkoruk 28,8 $\pm 10,7$ év volt, a legfiatalabb hallgató 18, a két legidősebb dolgozó pedig 59 éves volt. Lakhelyét tekintve összesen egy fó lakott a fóvárosban $(0,94 \%), 14$ fó élt megyeszékhelyen (13,21\%), 59 megkérdezett városban (55,66\%), míg 32-en éltek kisebb településeken $(30,19 \%)$. Családi állapot szerint 50 fó $(47,17 \%)$ egyedülálló volt, 30 fó $(28,30 \%)$ élettársi viszonyban élt, 23 fó $(21,70 \%)$ volt házas és 3 fó $(2,83 \%)$ elvált. A legmagasabb iskolai végzettséget tekintve összesen egy fó (0,94\%) rendelkezett csupán általános iskolai bizonyítvánnyal, 11 fő (10,38\%) végzett szakmunkásképzőt vagy szakiskolát, 83 fó $(78,30 \%)$ járt gimnáziumba vagy szakközépiskolába, 10 fönek $(9,43 \%)$ volt fóiskolai vagy egyetemi diplomája és egy fó $(0,94 \%)$ egyéb végzettséget szerzett, amelyet nem nevezett meg.

A mentödolgozók átlagosan 12,9ェ9,7 éve (legkevesebb 1 éve, legtöbb 38 éve) dolgoztak az Országos Mentőszolgálat kötelékében. A megkérdezettek között szerepelt 17 gépkocsivezető $(37,77 \%), 21$ ápoló $(46,66 \%)$ és 7 mentőtiszt $(15,55 \%)$. Közülük 21 fő $(46,66 \%)$ általában mentőgépkocsin teljesített szolgálatot (MGK), 7 fó $(15,55 \%)$ kiemelt mentőn (KIM-kocsin), 17 fö $(37,77 \%)$ pedig legtöbbször eset- vagy rohamkocsira volt beosztva.

A kutatásban összesen 61 mentôtiszthallgató vett részt. Közülük 11 fó (18,03\%) I. évfolyamos, 21 fó $(34,43 \%)$ II. évfolyamos, további 16 fó $(26,23 \%)$ III. éves, valamint 13 fó $(21,31 \%)$ végzős, azaz IV. éves hallgató válaszolt az általunk feltett kérdésekre.

\section{Halállal és haldoklással kapcsolatos élmények}

Az egész mintát tekintve a megkérdezettek közül 82 fó $(77,36 \%)$ találkozott már haldokló beteggel (hallgatók: 49 fó, 80,33\%, n = 61; dolgozók: 33 fó, 73,33\%, n = 45). Ezen válaszadók közül 43 fó rokoni kapcsolatban állt a haldoklóval, 6 fó ismerôsi viszonyban, 23 fö idegen személyt látott haldokolni, és 34 fó egyéb személyt, vagy nem találtunk jelölést; több válaszlehetőséget is megjelölhettek egyszerre a megkérdezettek.

Halottat összesen 69 fó $(65,09 \%)$ látott már életében (hallgatók: 39 fó, 63,93\%, n = 61; dolgozók: 30 fó, $66,67 \%, n=45)$. Közülük 45 fó $(65,22 \%)$ jelölte, hogy rokonságban, 4 fó $(5,80 \%)$ ismeretségi viszonyban állt a halottal, 16 fó $(23,19 \%)$ ismeretlen személyt jelölt, és végül 4 személy $(5,80 \%)$ már látott halottat, ám nem jelölte a kapcsolatukat.

\section{Halálfélelem a megkérdezettek körében}

A válaszadók halálfélelem-értékei az 1 ábrán láthatók. Ennek alapján elmondható, hogy a legerősebb félelem az egész mintát (11,5 $\pm 4,2$ pont) és a mentődolgozókat ( $11,3 \pm 4,2$ pont) tekintve is a nyolcadik, „Félelem a korai haláltól” faktorban tapasztalható. Ezzel szemben a mentőtiszthallgatók fiatalabb korosztálya a negyedik, „Jelentôs társak féltése" faktorban érte el a legalacsonyabb pontszámot $(10,6 \pm 3,6$ pont), amelynek megfelelően e szempont szerint mutatták a legjelentősebb félelmet. A legkevésbé félelmet keltő faktornak egyöntetûen a hetedik, „A test féltése a halál után” szempont bizonyult

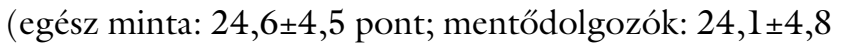
pont; PTE-hallgatók: $24,9 \pm 4,3$ pont).

A két vizsgált csoportot szemügyre véve a mentődolgozók halálfélelme erősebbnek bizonyult a II., III., VII. és a VIII. faktorokban, míg a PTE-hallgatók félelme az I., IV., V. és a VI. szempontok szerint volt jelentősebb. Statisztikailag igazolható összefüggés csak a IV., „Jelentôs társak féltése" faktorban volt megfigyelhető ( $\mathrm{p}=0,001)$, ahol is nagy valószínűséggel az életkorból és a tapasztalatok hiányából kifolyólag a hallgatók félelme volt jelentősebb.

\section{A balálfélelem mértékét befolyásoló tényezôk}

Az előzetes irodalmi adatoknak megfelelően az egyik jelentős különbséget a nemek tekintetében vártuk, amely a vizsgált mintában nem mutatott szignifikáns eltérést (2. ábra). A nők halálfélelme a legjelentősebb a negyedik faktorban („Jelentôs társak féltése” 11,13 pont), míg legkevésbé a hetedik faktortól félnek („A test féltése a balál után” 25,2 pont). Utóbbi faktor a férfiaknál is a legmagasabb pontszámot mutatta (VII. 24,1 pont), míg náluk a legjelentősebb szorongást a „Félelem a korai haláltól” faktor jelezte (11,2 pont). A nők erősebb halálfélelmet mutattak a „Félelem a meghalás folyamatától”, a „Félelem a halottól” és a „Félelem az ismeretlentôl” faktorokban. A férfiak alacsonyabb pontszámot értek el a skála „Félelem a megsemmisüléstôl”, a „Félelem a halál tudatos átélésétől”, a „Test féltése a halál után” és a „Félelem a korai haláltól” itemcsoportjai esetében.

Az életkor egyedül a „Jelentôs társak féltése” szempont szerint volt félelmet csökkentő tényező, miszerint minél idősebb volt egy válaszadó, annál magasabb pontszámot 


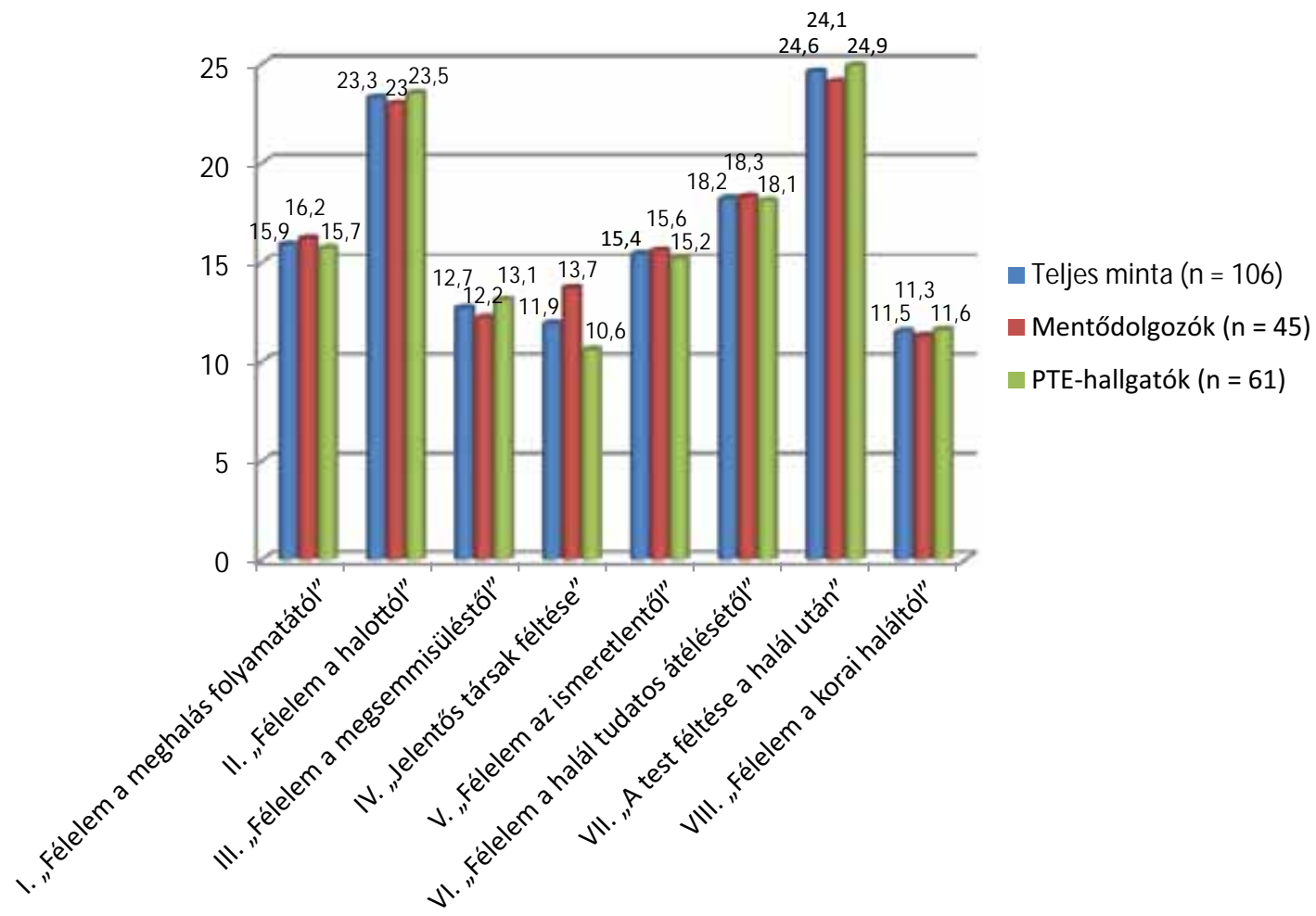

1. ábra

| A halálfélelem-értékek alakulása a MFODS-skála különböző faktoraiban

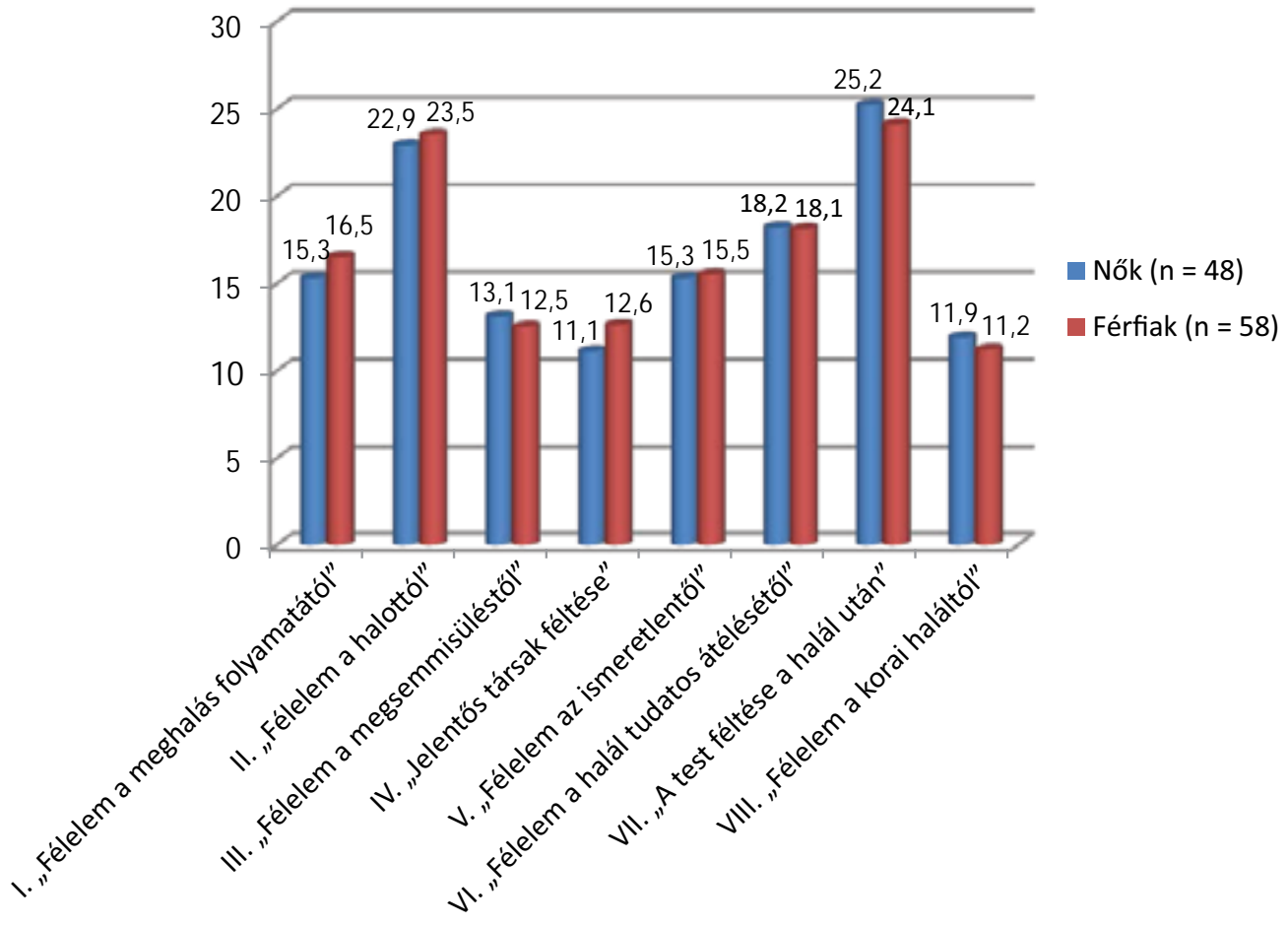

2. ábra

| A halálfélelem mértékének alakulása nemek szerint

kapott erre a faktorra, tehát annál kisebb volt a félelme $(\mathrm{p}=0,002)$.

A családi állapot, ennek megfelelően a társas támogatottság azonban jelentős befolyásoló erôvel bírt. Az egész mintát vizsgálva a „Jelentôs társak féltése” faktorban erőteljesebb volt a félelme az egyedülálló válaszadóknak

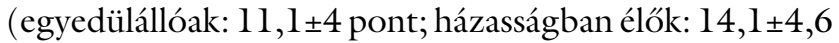
pont; $\mathrm{p}=0,039)$.

Az iskolai végzettség egyedül a „Jelentős társak féltése” faktorban mutatott szignifikáns kapcsolatot, miszerint azok, akik magasabb fokú tanulmányokkal rendelkeztek, alacsonyabb mértékü félelemról számoltak be (szakkö- 
zépiskolát végzettek: $13 \pm 4,7$ pont; egyetemet végzettek: $15,7 \pm 5,5$ pont; $\mathrm{p}=0,018$ ).

A halállal és haldoklással kapcsolatos előzetes tapasztalatok kevesebb befolyással bírtak, mint azt a vizsgálat elvégzése előtt feltételeztük. A baldokló beteg látványa két faktorban növelte a félelem mértékét („Félelem a halál tudatos átélésétól” $\mathrm{p}=0,006$; "Test féltése a balál után” $\mathrm{p}=0,018)$, míg a balállal való találkozás egyben („Félelem a halál tudatos átélésétôl” $\mathrm{p}=0,032$ ).

\section{Összefüggések a vizsgált célcsoportokban}

A mentötiszthallgatók körében az életkor egyedül a „Jelentós társak féltése" dimenzió félelemértékére gyakorolt hatást, ugyanis itt a III. évfolyamos hallgatók félelme szignifikánsan magasabbnak bizonyult, mint az elsőéveseké $(p=0,01)$. A nôi hallgatók erősebb félelemről számoltak be a „Félelem a balottól” faktort illetően, férfi társaikhoz képest $(\mathrm{p}=0,036)$. Az életkor előrehaladtával csökkent a tanulók félelme a „Félelem a korai haláltól” faktorban $(\mathrm{p}=0,036)$. Az egyedülállóak nagyobb félelmet mutattak a „Félelem a halál tudatos átélésétól” $(\mathrm{p}=$ $0,014)$ és a „Félelem az ismeretlentôl” $(\mathrm{p}=0,046)$ szempontok szerint. A haldokló látványának emléke szignifikánsan csökkentette a félelmet a „Félelem a halál tudatos átélésétól" dimenzióban ( $\mathrm{p}=0,017)$.

A mentödolgozók körében a válaszadó neme befolyással volt a félelem értékére a „Félelem a balál tudatos átélésétôl” faktorban $(\mathrm{p}=0,033)$, miszerint meglepó módon a férfiak erősebb félelmet mutattak. Az életkor és a munkában eltöltött évek nem voltak statisztikailag igazolható hatással, bár tendenciaként elmondható, hogy a kor és az OMSZ-nél eltöltött idő előrehaladtával nôtt a félelem mértéke a mentődolgozók vizsgált csoportjában. Meglepő módon az élettársi viszonyban élók nagyobb mértékű félelemről számoltak be a „Félelem a megsemmisüléstôl” faktorban, egyedülálló társaikhoz képest $(\mathrm{p}=0,027)$. A magasabb iskolai végzettséggel rendelkezők kevésbé féltek a „Félelem a balottól” faktor esetén $(\mathrm{p}=0,041)$. A haldoklással és a halott beteg látványával kapcsolatos tapasztalatok vizsgálatunkban igazolható módon nem befolyásolták a halálfélelem mértékét.

\section{Megbeszélés}

A vizsgálat fókuszában álló minta eredményei nagyban különböztek az eddigi felmérések eredményeitől, nagy valószínúséggel a célcsoport specifikumából (nemek aránya) és az elemszám nagyságából eredően. Míg az előzetes adatoknak megfelelően esetünkben is a „Jelentős társak féltése" bizonyult a leginkább félelmet keltő faktornak, további párhuzamot nem igazán tudunk vonni. Az életkor és a nemek tekintetében várt feltételezések nem igazolódtak, holott közel ugyanolyan arányban voltak a válaszadók között nők és férfiak, fiatalok és idősek. A mentőtiszthallgatók félelme egyedül a „Jelentös társak féltése” dimenzió szerint bizonyult magasabbnak, ami eredhet az alacsonyabb életkorból és a tapasztalás hiányából $(\mathrm{p}=0,001)$. Ezzel szemben a mentődolgozók körében a tapasztalás mértéke negatív irányba befolyásolta a félelmet, mivel a munkaévek előrehaladtával nagyobb mértékú halálfélelemról számoltak be a dolgozók.

A fokozott halálfélelem fokozott stresszel jár [22], ami a kiégéshez vezető út egyik lépcsőfoka. Ez ellen talán alkalmas eszköz lehet az ezzel kapcsolatos oktatás, a dolgozók körében pedig a pszichológiai támogatás, csoportterápiák, esetmegbeszélések formájában.

Anyagi támogatás: A közlemény megírása, illetve a kapcsolódó kutatómunka anyagi támogatásban nem részesült.

Szerzői munkamegosztás: P. E.: Szakirodalom gyüjtése, vizsgálati módszer felállítása, kézirat megszövegezése. SZ.-B. Z.: Kutatási eszköz kidolgozása, a vizsgálat lefolytatása (adatgyújtés). B. J.: Hipotézisek kidolgozása, kézirat megszövegezése. F. N.: Kutatási eszköz kidolgozása, statisztikai számítások elvégzése. A cikk végleges változatát valamennyi szerző elolvasta és jóváhagyta.

Érdekeltségek: A szerzőknek nincsenek érdekeltségeik.

\section{Irodalom}

[1] Tomer, A., Eliason, G.: Toward a comprehensive model of death anxiety. Death Stud., 1996, 20(4), 343-365.

[2] Makai, N. Cs.: The normal and complicated grief-related behaviors and the perception of support options. [A normál és komplikált gyászhoz kötődő viselkedésformák, valamint a támogató lehetőségek megítélése.] Kharón Thanatológiai Szemle, 2012, 16(3), 1-34. [Hungarian]

[3] www.ksh.hu [Hungarian]

[4] Bodrogi, J.: Demographic, economic and social context of aging. [Az idősödés néhány demográfiai, közgazdasági és társadalombiztosítási összefüggése.] Lege Artis Med., 2009, 19(8-9), 527530. [Hungarian]

[5] Tróznai, T., Kullmann, L.: The study regarding aging and the quality of life of the older people. [Az idős emberek életminőségének és idősödéssel kapcsolatos attitűdjeinek vizsgálata.] Lege Artis Med., 2007, 17(2), 137-143. [Hungarian]

[6] Graber, H., Magyar, T.: Treatment at the end of life. [Kezelés az élet végén.] Lege Artis Med., 2003, 13(5), 360-363.

[7] Zana, A., Konkoly Thege, T. B.: Is profession associated with fear of death? [Összefüggésbe hozható-e a halálfélelem a foglalkozással?] Orv. Hetil., 2014, 155(31), 1236-1240. [Hungarian]

[8] Neimeyer, R. A., Moore, M. K.: Validity and reliability of the Multidimensional Fear of Death Scale. In: Neimeyer R. A. (ed.): Death Anxiety Handbook. Taylor and Francis, New York, 1994, 103-119.

[9] Zana, Á., Hegeduss, K., Szabó, G.: Validity and reliability of Multidimensional Fear of Death Scale in Hungarian population. [A Neimeyer és Moore-féle Multidimenzionális Halálfélelem Skála validálása magyar populáción.] Mentálhigiéné és Pszichoszomatika, 2006, 7(3), 257-266. [Hungarian]

[10] Zana, Á., Szabó, G., Hegedüs, K.: The comparative study of the relationship between fear of death, attitudes towards death and mental health. [A halálfélelem, a halál iránti attitűd és a mentális egészség kapcsolatának korosztályos összehasonlító vizsgálata.] Lege Artis Med., 2008, 18(4), 319-320. [Hungarian] 
[11] Cicirelli, V. G.: Personal meanings of death in older adults and young adults in relation to their fears of death. Death Stud., 2001, 25(8), 663-683.

[12] Zana, A.: Death attitude and changes of death image in the Hungarian society. Examination of generational value-judgment and possibilities of measurement. Is death still a taboo? [A halálkép alakulása és változása Magyarországon, a korosztályos értékítélet-különbségek és a lehetséges mérési módszerek vizsgálata. Tabu-e még a halál?] Orv. Hetil., 2009, 150(25), 1183-1187. [Hungarian]

[13] Gregov, L., Kovačević, A., Slišsović, A.: Stress among Croatian physicians: comparison between physicians working in emergency medical service and health centers: pilot study. Croat. Med. J., $2011,52(1), 8-15$

[14] Sterud, T., Hem, H., Ekeberg, Q., et al.: Occupational stressors and its organizational and individual correlates: A nationwide study of Norwegian ambulance personnel. BMC Emerg. Med., $2008,8,16$

[15] Venegas, M. E., Alvarado, O. S., Barriga, O.: Validation of Collett-Lester's Fear of Death Scale in a sample of nursing students. Rev. Lat. Am. Enfermagem, 2011, 19(5), 1171-1180.

[16] Hegedüs, K., Pilling, J., Kolosai, N.: The attitudes of nurses and medical students regarding death and dying. [Ápolók és medikusok halállal és haldoklással kapcsolatos attitúdje.] Lege Artis Med., 2001, 11(6-7), 492-499. [Hungarian]

[17] Dickinson, G. E.: Teaching end-of-life issues in US medical schools: 1975 to 2005. Am. J. Hosp. Palliat. Care, 2006, 23(3), 197-204.
[18] Roff, L. L., Butkeviciene, R., Klemmack, D. L.: Death anxiety and religiosity among Lithuanian health and social service professionals. Death Stud., 2002, 26(9), 731-742.

[19] Zana, Á., Szabó, G., Hegedüs, K.: The development and change of death image in Hungary. Differences in value judgement according to age and analysis of possible measurement methods. Is death still a taboo? Thesis. Clin. Exp. Med. J., 2009, 3(2), 353359.

[20] Hamama-Raz, Y., Solomon, Z., Ohry, A.: Fear of personal death among physicians. Omega, 2000, 41(2), 139-149.

[21] Hegedüs, K., Pilling, J., Kolosai, N., et al.: Attitude of physicians toward death and dying. [Orvosok halállal és haldoklással kapcsolatos attitúdjei.] Orv. Hetil., 2002, 143(42), 2385-2391.

[22] Marosvölgyi, Zs. M.: Examination of the human mind. The fear of death and the change in values due to the near-death experience. [Az emberi tudat vizsgálata. A halálfélelem és az értékrend változása a halálközeli élmény hatására.] Kharón Thanatológiai Szemle, 2008, 12(3-4), 16-52. [Hungarian]

(Pék Emese,

Pécs, Vörösmarty M. út 4., 7621 e-mail: emese.pek@etk.pte.hu)

\section{Tisztelt Szerzőink, Olvasóink!}

Az Orvosi Hetilapban megjelenő/megjelent közlemények elérhetőségére több lehetőség kínálkozik.

Rendelhető különlenyomat, melynek áráról bővebben a www.akkrt.hu honlapon (Folyóirat Szerzőknek, Különlenyomat menüpont alatt) vagy Szerkesztöségünkben tájékozódhatnak.

A közlemények megvásárolhatók pdf-formátumban is, illetve igényelhetö Optional Open Article (www.oopenart.com).

Adott dij ellenében az online közlemények bárki számára hozzáférhetök honlapunkon (a közlemények külön linket kapnak, így más oldalról is linkelhetővé válnak).

Bővebb információ a hirdetes@akkrt.hu címen vagy különlenyomat rendelése esetén a Szerkesztőségtől kérhető. 